\title{
FASILITAS PENGOLAHAN SAMPAH PLASTIK DAN GALERI EDUKASI DI KAMPUNG MELAYU
}

\author{
Pramukti Siswo Sunarno ${ }^{1)}$, Petrus Rudi Kasimun ${ }^{2)}$ \\ 1)Program Studi S1 Arsitektur, Fakultas Teknik, Universitas Tarumanagara, \\ pramukti.315150199@stu.untar.ac.id \\ 2) Program Studi S1 Arsitektur, Fakultas Teknik, Universitas Tarumanagara, petrusk@ft.untar.ac.id
}

\begin{abstract}
Abstrak
Peningkatan timbunan sampah, khususnya sampah plastik, merupakan masalah yang paling sering dihadapi oleh masyarakat di lingkungan perkotaan. Arsitektur selalu berkaitan erat dengan permukiman dan juga lingkungan. Dengan adanya sampah plastik ini maka permasalahan yang timbul di kawasan permukiman pasti bermacam-macam, diantaranya timbul suasanya tidak nyaman di sekitar kawasan permukiman. Namun selama ini permasalah yang ada belum tertuntaskan secara strategis sehingga dampak-dampak negatif selalu timbul bersama lingkungan dan masyarakat. Untuk solusi yang ditawarkan dalam menghadapi kasus ini adalah sebuah rancangan untuk mewadahi terkait dengan pengelolaan sampah dalam beraktifitas. Pengolahan dan pengelolaan sampah plastik harus dilakukan melalui penerapan keberlanjutan lingkungan yang mampu mengintegrasikan pengelolaan berbasis ekologi dan wadah untuk masyarakat dalam mempelajari nilai penting dari sampah baik secara negatif maupun positif. Dengan mengusulkan sebuah wadah fasilitas pengolahan sampah plastik dan juga galeri untuk pameran benda-benda seni yang terbuat dari sampah plastik dan bengkel kerja kerajinan tangan dari sampah plastik, bangunan ini diharapkan dapat mengurangi dampak timbunan sampah plastik di kampung melayu. Area pameran pada bangunan ini juga merupakan sebagai salah satu cara untuk menyentuh masyarakat tentang edukasi persampahan dan menjadi tempat wisata baru yang berhubungan dengan tempat wisata lain disekitarnya sekaligus memecahkan permasalahan sampah di lingkungan dan workshop yang menciptakan barang-barang kreatif dan keunikan yang dapat menarik para pengunjung.
\end{abstract}

Kata kunci: Galeri Edukasi; Pengolahan Sampah Plastik; Permasalahan Sampah Plastik; Sampah Plastik; Seni

\begin{abstract}
The increase of solid waste production is a general problem in municipality, particularly of plastic waste. Architecture is always closely related to settlements and the environment. With this plastic waste, the problems that arise in residential areas must be various, including an uncomfortable atmosphere around residential areas. However, so far the existing problems have not been resolved strategically so that negative impacts always arise with the environment and society. For the solution offered in dealing with this case is a design to accommodate those related to waste management in activities. Processing and management of plastic waste must be carried out through the application of environmental sustainability that is able to integrate ecology-based management. By proposing a plastic waste processing facility as well as a gallery for exhibitions of art objects made of plastic waste and a workshop for handicrafts made of plastic waste, this building is expected to reduce the impact of plastic waste accumulation in Malay villages. The exhibition area in this building is also a way to touch the community about waste education and become a new tourist spot that is related to other tourist attractions in the vicinity as well as solving waste problems in the environment and workshops that create creative and unique items that can attract visitors.
\end{abstract}

Keywords: Art; Educational Gallery; Plastic waste ; Plastic Waste Problems; Plastic Waste Processing 


\section{PENDAHULUAN}

Penggunaan plastik di dunia terus meningkat, termasuk di Indonesia. Hal ini menyebabkan peningkatan volume sampah plastik dari tahun ke tahun. Penggunaan plastik dalam kehidupan sehari-hari menyebabkan timbulan sampah yang menyebabkan permasalahan baru karena plastik sulit terurai. Perlu puluhan hingga ratusan tahun agar plastik dapat terurai oleh alam. Bahkan ketika plastik telah terurai menjadi microplastic pun masih berbahaya bagi kehidupan makhluk di bumi ini.

Permasalahan sampah plastik di Indonesia sudah sampai pada tahap yang mengkhawatirkan dan memerlukan usaha yang maksimal untuk dapat mengolahnya kembali. Tingginya tingkat pertumbuhan penduduk dan perkembangan ekonomi membantu meningkatkan minat penggunaan plastik di sekitaran lingkungan masyarakat indonesia. Plastik, sebagai komoditas utama yang memiliki berbagai manfaat, sehingga menjadikan plastik dapat digunakan dalam berbagai industri. Dampaknya, timbunan sampah plastik di Indonesia menjadi semakin meningkat tiap tahun nya. Berdasarkan data Kementrian Lingkungan Hidup dan kehutanan (KLHK) pada tahun 2016, sampah plastik yang dihasilkan di Indonesia dari sekitar 90 ribu gerai ritel modern mencapai 9,85 miliar lembar sampah kantong plastik (Sakti, 2019). Indonesia juga dikenal sebagai negara kedua terbesar penghasil sampah plastik di laut setelah Cina dengan pencapaian 187,2 juta ton sampah plastik (Jambeck, 2015).

Jakarta merupakan daerah penyumbang sampah plastik terbesar di Indonesia, Khususnya Jakarta Timur. Tercatat pada tahun 2019 jumlah ritasi truk sampah yang masuk ke Tempat Pengolahan Sampah Terpadu (TPST) sebanyak 36.991 ritasi dengan sampah 205 ribu ton sampah setiap bulannya. Artinya, setiap truk sampah membawa sampah sekitar 5,6 ton sampah setiap bulannya. Jakarta Timur merupakan lokasi yang dipilih dalam penempatan Fasilitas Pengolahan Sampah Plastik dan Galeri Edukasi tepatnya di JL. Otto Iskandardinata Kelurahan Kampung Melayu. Lokasi dipilih karena memenuhi kriteria yang dibutuhkan, yaitu dikelilingi oleh Pemukiman Padat Penduduk, Universitas, Kantor dan Sekolah menjadikan peluang yang besar sebagai wadah untuk mengolah sampah plastik. Kurangnya pengetahuan masyarakat akan bagaimana cara mengelolah sampah plastik di sekitaran lokasi juga menjadikan bahan pertimbangan dalam pemilihan Progam Galeri Edukasi.

Tujuan pada perancangan Fasilitas Pengolahan Plastik dan Galeri Edukasi ini adalah guna mengatasi masalah sampah plastik di Jakarta. Salah satu kegiatan yang diwadahi yaitu pembangunan fasilitas pengolahan sampah dalam kota atau Intermediate Treatment Facility (ITF) untuk mengurangi sampah plastik dari sumbernya. Kegiatan strategis lainnya adalah Bank Sampah Masyarakat yang menggiatkan keterlibatan masyarakat dengan instansi terkait setempat. Selain itu, fasilitas ini juga memiliki maanfaat sebagai sarana Edukasi dan Wisata bagi masyarakat sekitar Jakarta Timur.

\section{KAJIAN LITERATUR}

\section{Ekologi}

Di dalam sejarah ilmu pengetahuan tentang kehidupan, sebenarnya sejak dahulu kala, pemikir ulung, seperti Aristoteles, Hipocrates, dan pakar filosofi dari Yunani yang lain sudah mewarnai ajarannya dengan berbagai konsep ekologi. Makna kehidupan tentang peluang adanya keserasian, godaan kehidupan sehingga menyebapkan timbulnya bencana yang mengancam kelangsungan peradaban, semuanya merupakan konsep, prinsip maupun hukum dasar yang mewarnai ekologi. Pada awal tahun 1700, seorang ahli mikrobiologi Antonie van Leeuwenhoek dalam pengamatannya terhadap jasad renik telah melihat adanya gejala rantai makanan, pengaturan populasi dan strategi hidup yang merupakan fenomena penting dalam ekologi. 
Ahli botani lain Richard Bradly mengungkapkan konsep tentang produktivitas hayati, yang merupakan subjek lain dan juga merupakan inti dari ekologi. Sampai saat itu pun sebenarnya belum dikenal istilah ekologi, dan baru pada tahun 1869 diperkenalkan istilah ekologi oleh Ernst Haeckel, seorang ahli biologi Jerman yang menekankan adanya hubungan timbal-balik antar semua komponen kehidupan dalam satu sistem. Berbagai konsep, prinsip dan hukum dalam kehidupan yang dipelajari dalam ekologi sudah dipikirkan oleh para pakar sebelumnya. Hukum minimum dari Justus von Liebig tentang faktor utama yang menentukan mutu atau keadaan suatu sistem sudah dikembangkan sejak tahun 1840. Demikian pula konsep tentang keanekaragaman hayati, suksesi, toleransi dan sebagainya, dasar-dasarnya sudah dikemukakan oleh para ahli biologi sebelum munculnya cabang ilmu pengetahuan tentang ekologi.

Oleh karena itu, sering kali sampai tahun 1970-an ekologi dianggap sebagai cabang dari biologi. Namun, di kemudian hari dengan merebaknya berbagai isu lingkungan hidup antara tahun 19681970 walaupun tetap mempunyai hubungan yang erat dengan biologi, tetapi ekologi mulai dilihat sebagai ilmu tersendiri yang interdisiplin, serta berdasarkan disiplin yang integratif yang mengaitkan berbagai proses fisik dan hayati. Bahkan digunakan untuk menjelaskan seluk-beluk kota dengan apa yang disebut ekologi kota, seluk-beluk administrasi melalui pendekatan ekologi administrasi dan sebagainya.

Kata 'melampaui' pada tema soal lebih berupa cara pandang untuk melihat ke luar, bagaimana hubungannya dengan objek-objek di lingkungan sekitar dalam kaitan terhadap ruang dan waktu. Agustinus Sutanto menyimpulkan terdapat 6 parameter dalam arsiktektur menuju melampaui (beyond) ekologi yang dapat digunakan yaitu:

1. Energy and Emission

Kemampuan untuk menerapkan zero $\mathrm{CO} 2$ emission dalam pengoperasionalan bangunan dan meminimalisis efek karbon dalam material dan konstruksi.

2. Adaptation

Kemampuan untuk melakukan riset dan desain yang berkaitan dengan berbagai dampak, seperti naiknya suhu bumi, naiknya permukaan laut, kekeringan, banjir, kelangkaan pangan, perubahan populasi dan lain sebagainya.

3. Resilience

Kemampuan untuk membangun kelanjutan 'hunian' dan pemulihan cepat setelah kejadian guncangan, bencana alam, gangguan listrik atau iklim.

4. Sustainable Digital

Kemampuan untuk melihat data-data lingkungan sebagai big data dalam menentukan taktik dan strategi dalam membangun kualitas spasial.

5. New Technology

Kemampuan memanfaatkan teknologi terbaru untuk meningkatkan kualitas terapan ruangkonstruksi dan program bangunan

6. Context

Kemampuan dalam melihat posisi 'tempat' dalam hubungan dengan lingkungan (flora-fauna, biotik-abiotik) dimana sebuah konfigurasi keruangan akan ditempatkan.

\section{Sampah}

Definisi Sampah

Sampah adalah hasil buangan dari suatu proses produksi baik industri maupun domestik (rumah tangga). Definisi World Health Organization (WHO) sampah adalah sesuatu yang tidak digunakan, tidak dipakai, tidak disukai atau sesuatu yang dibuang yang berasal dari proses kegiatan manusia dan tidak terjadi dengan sendirinya (Chandra, 2006). UU No 18 Tahun 2008 tentang Pengelolaan Sampah, menyebutkan sampah adalah sisa dari berbagai proses kegiatan setiap hari yang dilakukan oleh manusia ataupun proses alam yang berbentuk padat atau semi 
padat berupa zat organik atau anorganik bersifat dapat terurai atau tidak dapat terurai yang dianggap sudah tidak bermanfaat dan dibuang ke lingkungan (Slamet, 2002).

Menurut Tchobanoglous, et al (1993), sampah adalah semua jenis bahan padat termasuk cairan dalam kontainer yang dibuang atau diafkir sebagai bahan buangan, tidak digunakan atau barangbarang yang dibuang karena berlebihan. Pengertian sampah menurut Sudrajat (2008), menyebutkan bahwa sampah atau waste adalah hasil seluruh kegiatan dari suatu bahan yang terbuang atau dibuang oleh manusia maupun alam dan belum memiliki manfaat ekonomis.

Berdasarkan beberapa pengertian tentang sampah maka dapat didefinisikan sampah adalah sisa bahan, limbah atau buangan yang bersifat padat, setengah padat termasuk juga cairan yang merupakan hasil sampingan dari aktifitas atau siklus kehidupan manusia, hewan maupun tumbuh-tumbuhan yang dianggap sudah tidak bermanfaat dan belum memiliki nilai ekonomis serta dibuang ke lingkungan.

\section{Sampah Plastik}

Menurut saya, Sampah Plastik adalah Jenis sampah anorganik yang tidak dapat diuraikan begitu saja butuh waktu bertahun - tahun untuk dapat diuraikan.

\section{Pengelolaan Sampah}

Merupakan pengendalian terhadap timbulan sampah, penyimpanan, pengumpulan, pemindahan dan pengangkutan, pengolahan, dan pembuangan sampah dengan suatu cara yang sesuai dengan prinsip-prinsip terbaik yang berhubungan dengan kesehatan masyarakat, ekonomi, tehnik, perlindungan alam, keindahan dan pertimbangan lingkungan lainnya serta mempertimbangkan masyarakat luas (Tchobanoglous, et al, 1993).

Pengelolaan Sampah menurut Undang-Undang No.18 Tahun 2008 merupakan suatu kegiatan mengurangi dan menangani sampah yang sistematis, menyeluruh, dan berkesinambungan yang meliputi pengurangan dan penanganan sampah. Undang-Undang tersebut menegaskan bahwa pengelolaan sampah harus dilakukan secara komprehensif dari hulu sampai hilir. Kegiatan mengurangi dan menangani sampah terkait erat dengan konsep $3 \mathrm{R}$, yang terdiri dari reduce (mengurangi timbulan sampah pada sumber), reuse (pakai ulang), recycle (daur ulang) yaitu mendaur ulang barang-barang yang sudah tidak berguna lagi dan memanfaatkan sampah menjadi barang lain.

\section{Sistem Pengelolaan Persampahan}

Usaha mengatur atau mengelola sampah dimulai dari proses pengumpulan, pemisahan, pemindahan sampai pengolahan dan pembuangan akhir (Cipta Karya, 1993). Pengelolaan sampah terdiri dari dua jenis yaitu pengelolaan setempat (individu) dan pengelolaan terpusat untuk lingkungan atau perkotaan. Menurut Kodoatie (2003), pada dasarnya sistem pengelolaan sampah perkotaan dapat dilihat dari komponen-komponen yang saling mendukung satu dengan yang lain saling berinteraksi untuk mencapai tujuan yaitu kota yang bersih, sehat dan teratur. Komponen tersebut adalah aspek teknik operasional, aspek kelembagaan, aspek pembiayaan, aspek hukum dan pengaturan, dan aspek peran serta masyarakat. Sistem pengelolaan limbah padat perkotaan diperlukan tindakan terkoordinatif, sinkronisasi dan simplikasi.

\section{Dampak Negatif Sampah}

Dampak sampah padat yang bertumpuk dalam waktu yang lama dan tidak dapat terurai akan mencemari tanah. Kategori sampah adalah suatu bahan yang 27 tidak terpakai karena bagianbagian utamanya sudah diambil dengan pengolahan menjadi bagian yang tidak disukai dan secara ekonomi tidak ada harganya. Menurut Gelbert, et al (1996), ada tiga dampak negatif 
sampah terhadap manusia dan lingkungan yaitu dampak terhadap kesehatan, dampak terhadap lingkungan, dampak terhadap keadaan sosial dan ekonomi.

1. Dampak Terhadap Kesehatan

Lokasi yang kurang memadai dan tidak terkontrol dalam pengelolaan/pembuangan sampah merupakan tempat berkembangbiak organisme bagi berbagai binatang seperti, lalat dan tikus yang dapat menyebabkan penyakit. Potensi bahaya kesehatan yang timbul yaitu penyakit seperti diare, kolera, tifus yang menyebar dengan cepat karena virus yang berasal dari sampah dengan pengelolaan tidak tepat dapat bercampur air minum.

Meningkatnya penyakit demam berdarah (haemorhagic fever) dengan cepat di daerah yang pengelolaan sampahnya kurang memadai. Penyakit jamur dapat menyebar misalnya jamur kulit dan penyakit cacingan dapat menyebar melalui rantai makanan yang ditularkan oleh cacing pita (taenia). Cacing ini sebelumnya masuk kedalam pencernakan binatang ternak melalui makanannya yang berupa sisa makanan/sampah.

2. Dampak Terhadap Lingkungan

Ekosistem perairan biologis akan berubah bila berbagai cairan rembesan sampah yang masuk kedalam drainase atau sungai mencemari air, sehingga beberapa spesies akan lenyap, termasuk ikan akan mati akibat berubahnya ekosistem perairan biologis. Penguraian sampah yang di buang kedalam air akan 28 menghasilkan asam organik dan gas cair organik, seperti metana. Selain memiliki bau yang kurang sedap, gas ini pada konsentrasi tinggi dapat meledak.

3. Dampak terhadap keadaan sosial dan ekonomi

Tingkat kesehatan masyarakat akibat pengelolaan sampah yang tidak memadai sehingga meningkatnya pembiayaan untuk berobat ke pelayanan kesehatan. Infrastruktur persampahan yang tidak memadai mempengaruhi pengelolaan sampah akibatnya biaya yang diperlukan untuk pengolahan air semakin tinggi apabila sarana penampungan sampah kurang efisien dan kebiasaan membuang sampah di jalan sehingga jalan perlu dibersihkan dan diperbaiki.

\section{Partisipasi Masyarakat dalam Pengolahan Sampah}

Menurut Yolarita (2011), dalam pengelolaan sampah, partisipasi masyarakat dapat berupa pemilahan antara sampah organik dan sampah anorganik pada saat proses pewadahan, atau melalui pembuatan kompos dalam skala keluarga dan mengurangi penggunaan barang yang tidak mudah terurai. Konsep partisipasi menurut Candra (2012), diukur melalui tahap perencanaan, tahap pelaksanaan, dan tahap pemanfaatan. Partisipasi masyarakat dalam pengelolaan sampah bukan hanya dilihat dari keikutsertaan masyarakat dalam proses pelaksanaan pengelolaan sampah, namun keikutsertaan menjadi anggota organisasi yang berkaitan dengan masalah sampah dan berperan dalam merencanakan sistem pengelolaan sampah yang baik.

Menurut Yuliastuti, et al (2013) partisipasi masyarakat dalam pengelolaan sampah secara tidak langsung yaitu keterlibatan masyarakat dalam masalah keuangan dengan cara membayar retribusi pelayanan persampahan. Salah satu bentuk partisipasi terhadap pengelolaan sampah berupa kesediaan membayar (willingness to pay) untuk peningkatan fasilitas pengelolaan sampah agar kebersihan dan kualitas lingkungan tetap terjaga (Manurung, 2008).

Kesimpulan dari paparan tentang partisipasi masyarakat dalam pengelolaan sampah yaitu keikutsertaan masyarakat baik secara langsung maupun tidak langsung dalam upaya mengelola sampah menjadi suatu benda lain yang bermanfaat. Partisipasi dalam pengelolaan sampah 
dapat dilakukan oleh masyarakat dengan banyak cara, baik dalam bentuk sumbangan tenaga, ide, pikiran, maupun materi. Partisipasi merupakan modal terpenting dalam pengelolaan sampah untuk keberhasilan mengatasi permasalahan sampah rumah tangga terutama di perkotaan.

\section{Edukasi}

Menurut Notoadmojo (2005) menyebutkan bahwa Edukasi atau disebut juga dengan pendidikan merupakan segala upaya yang direncanakan untuk mempengaruhi orang lain baik individu, kelompok, atau masyarakat sehingga mereka melakukan apa yang diharapkan oleh pelaku Pendidikan. Menurut Driyarkara (2006) menyebutkan bahwa pengertian edukasi adalah suatu usaha di dalam memberikan peganggan kepada manusia serta juga mengangkat yang muda supaya lebih insani. Terutama, di dalam mensiasati perkembangan jaman yang berjalan dengan begitu cepat. Penting, supaya manusia itu untuk tetep bisa menyesuaikan sebagai peranannya.

\section{Fasilitas}

Fasilitas merupakan wadah dari segala macam kegiatan yang sengaja disediakan oleh penyedia jasa untuk dipakai serta dinikmati oleh konsumen yang bertujuan memberikan tingkat kepuasan yang maksimal. Fasilitas merupakan segala sesutau yang bersifat peralatan fisik yang disediakan oleh pihak penjual jasa untuk mendukung kenyamanan konsumen (Kotler, 2009: 45). Menurut Tjiptono (2006: 43) desain dan tata letak fasilitas jasa erat kaitannya dengan pembentukan presepsi pelanggan. Sejumlah tipe jasa, presepsi yang terbentuk dari interaksi antara pelanggan dengan fasilitas berpengaruh terhadap kualitas jasa tersebut di mata pelanggan. Sedangkan Menurut Lupioadi, (2008: 148) Fasilitas merupakan penampilan, kemampuan sarana prasarana dan keadaan lingkungan sekitarnya dalam menunjukkan eksistensinya kepada eksternal yang meliputi fasilitas fisik (gedung) perlengkapan dan peralatan. Yang termasuk fasilitas dapat berupa alat, benda-benda, perlengkapan, uang, ruang tempat kerja.

\section{Galeri}

Menurut arti bahasanya, Pengertian galeri dapat dijelaskan sebagai berikut:

1. Menurut Pusat Bahasa Departemen Pendidikan Nasional (2003): Galeri adalah selasar atau tempat; dapat pula diartikan sebagai tempat yang memamerkan karya seni tiga dimensional karya seseorang atau sekelompok seniman atau bisa juga di definisikan sebagai ruangan atau Gedung tempat untuk memamerkan benda atau karya seni.

2. Menurut Oxford Advanced Learner's Dictionary, A.S Hornby, edisi kelima, Great Britain: Oxford University Press, (1995): "Gallery; A room or building for showing Work of Art ".

3. Menurut Kamus Inggris-Indonesia, An English-Indonesian Dictionary, (1990): "Galeri; Serambi, Balkon, Balai atau Gedung Kesenian.

Menurut Encyclopedia of American Architecture (1975), Galeri diterjemahkan sebagai suatu wadah untuk menggelar karya seni rupa. Galeri juga dapat diartikan sebagai tempat menampung kegiatan komunikasi visual di dalam suatu ruangan antara kolektor atau seniman dengan masyarakat luas melalui kegiatan pameran. Sebuah ruang yang digunakan untuk menyajikan hasil karya seni, sebuah area memajang aktifitas public, area public yang kadang kala digunakan untuk keperluan khusus (Dictionary of Architecture and Construction, 2005).

\section{METODE}

Metode desain yang digunakan dalam proses mendesain bangunan fasilitas pengolahan sampah plastik dan galeri edukasi di Kampung Melayu adalah Metode Analitis (Analitical Method). Hal ini mengacu pada metodologi desain (Jones, 1971) sebagai formulasi dari apa yang dinamakan "berfikir sebelum menggambar" ("thinking before drawing"). Metode ini merupakan metode dasar yang didalamnya dapat dipilah lagi dalam metode-metode pendekatan yang lebih spesifik, 
yang akan diuraikan dalam pembahasan selanjutnya. Dalam metode analitis ini hasil rancangan akan sangat dipengaruhi oleh proses yang dilakukan sebelumnya. Proses tersebut meliputi penepatan masalah, pendataan lapangan, literature, tipologi, analisis pemroframan, sintesis, skematik desain, penyusunan konsep dan perwujudan desain.

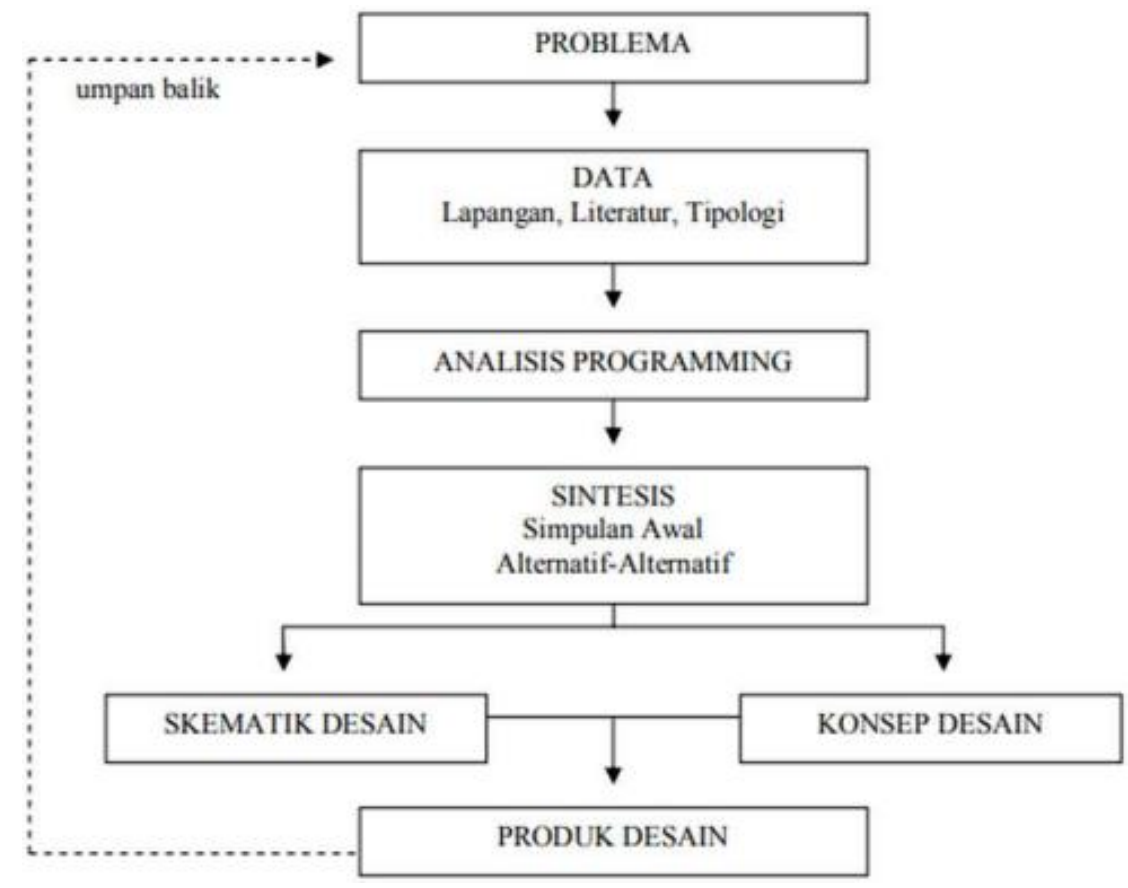

Gambar 1. Metode Desain Analitis Sumber: Dokumen Pribadi

\section{DISKUSI DAN HASIL}

Pemilihan kawasan dipilih berdasarkan karakteristik Pengolahan Sampah Plastik dan Galeri Edukasi. Pengolahan Sampah Plastik disini berperan sebagai fasilitas yang mewadahi kekurangan dari aspek yang belum ada. Aspek Galeri Edukasi ini sendiri berperan selain menjadi tempat pendidikan, Galeri ini juga dapat menjadi pengenalan terhadap beberapa hasil pengolahan sampah plastik yang masih dapat dipergunakan kembali.

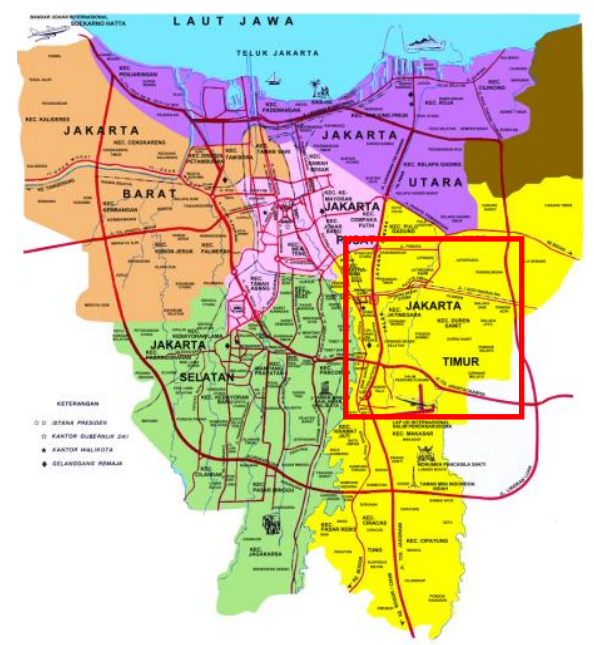

Gambar 2. Peta Jakarta

Sumber: https://id.wikipedia.org/wiki/Berkas:Peta_Jakarta.gif 


\section{Pemilihan tapak secara Makro}

Lokasi pemilihan tampak berada di Kampung Melayu Jakarta timur tepatnya di sepanjang Jl. Otto Iskandardinata karena daerah ini tergolong daerah yang padat dengan penduduk dan pemukiman kumuh dimana menjadi Sumber Sampah Plastik Rumah tangga berasal. Kondisi perekonomian yang tergolong menengah-kebawah menjadikan masyarakat sekitar kurang mendapat edukasi seputar pentingnya bagaimana mengolah sampah dan kesadaran akan bahaya sampah itu sendiri.

\section{Pemilihan Tapak secara Mezzo}

Pemilihan tapak terdapat di Jl. Otto Iskandardinata tepatnya di kelurahan Kampung Melayu. (Gambar 3)

\section{Jakarta Timur}

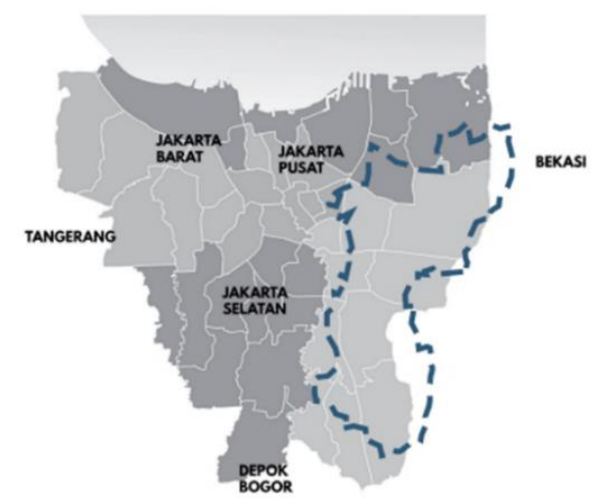

Gambar 3. Peta Kawasan Jakarta Timur Sumber: https://www.sketchbubble.com/en/presentation-jakarta-map.html

Tabel 1. Tabel SWOT

\begin{tabular}{cccc}
\hline Strength & Opportunity & Weakness & Threat \\
\hline Jalan tidak macet & $\begin{array}{c}\text { Fasilitas transportasi cukup } \\
\text { memadahi }\end{array}$ & Daerah rawan banjir & - \\
\hline $\begin{array}{c}\text { Tapak datar tidak } \\
\text { berundak }\end{array}$ & $\begin{array}{c}\text { Banyak fasilitas pendidikan } \\
\text { seperti SD, SMP, SMA, Sekolah } \\
\text { Tinggi }\end{array}$ & \\
\hline $\begin{array}{c}\text { Berada di depan } \\
\text { jalan Arteri }\end{array}$ & $\begin{array}{c}\text { Banyak toko dan warung yang } \\
\text { buka hingga malam hari }\end{array}$ & \\
\hline
\end{tabular}

Sumber: Dokumen Pribadi

Pemilihan Tapak secara Mikro 


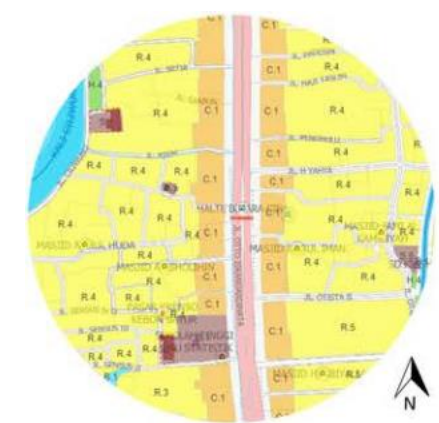

Gambar 4. Peta Zonasi Kawasan

Sumber : https://jakartasatu.jakarta.go.id/

Tapak berada di Zona Campuran, di kecamatann Jatinegara, Kelurahan Kampung Melayu dengan KDB 60\%, KLB 2,4\%, Ketinggian Bangunannya 4 lantai, Kdh 30\%, KTB 55\%, dan diizinkan untuk Fasilitas Edukasi, Ruang Pertemuan, Taman Rekreasi, Multifungsi (Mixed-use) dan Tempat Pengolahan Sampah-3R. Tapak berada pada JL. Otto Iskandardinata dengan Sirkulasi utama kendaraan untuk pintu masuk dan keluar kendaraan berada pada arah Jalan Otto Iskandardinata dengan lebar jalan sebesar $16 \mathrm{~m}$ sedangkan sirkulasi utama bagi pedestrian akan berada pada Jalan Kebun Sayur yang merupakan jalan penghubung antara rumah masyarakat dengan proyek sehingga saling mendekatkan bangunan dan lingkungan masyarakat.

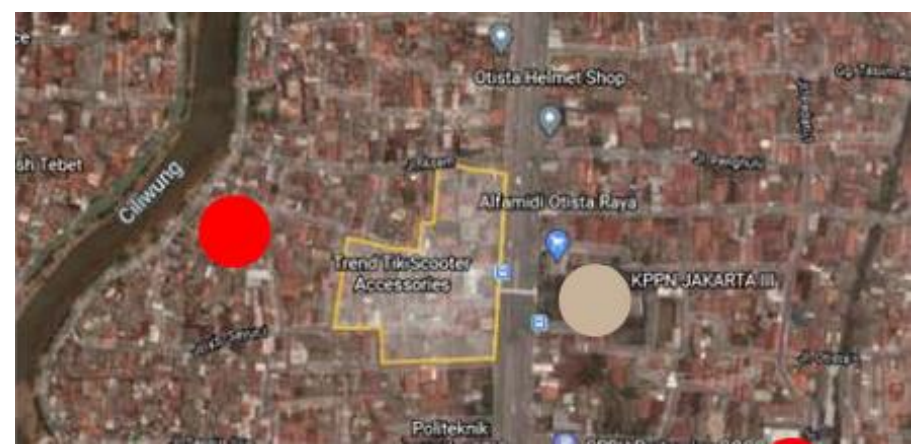

Gambar 5. Lokasi tapak yang dipilih Sumber: Google Earth

Kondisi dari existing sekitar tapak yang mendukung berupa aktivitas publik seperti bangunan pemerintahan, sekolah, universitas, dan pemukiman padat penduduk.

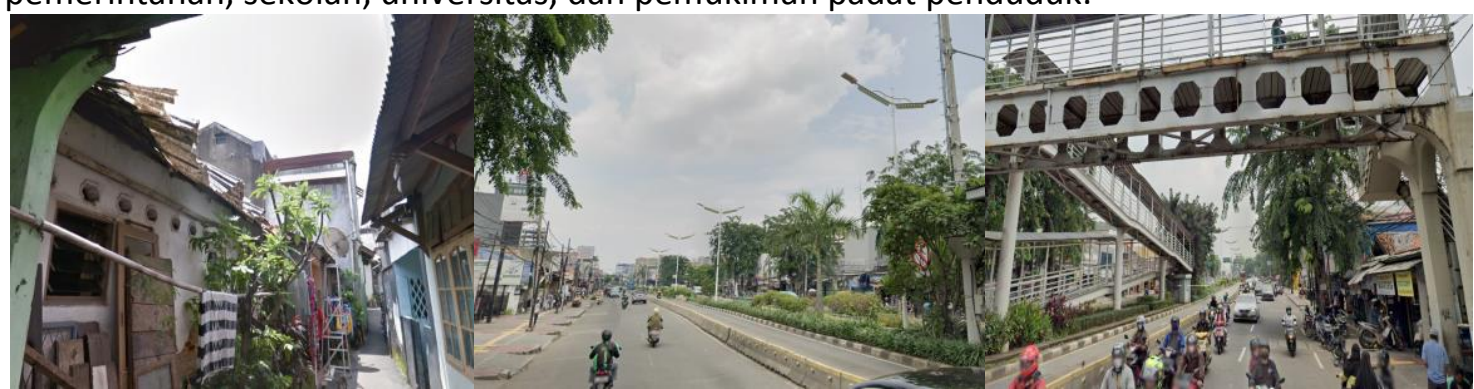

Gambar 6. Lokasi tapak

Sumber: Google Maps

Kondisi Aksesibilitas Jalan di Jakarta Timur : 


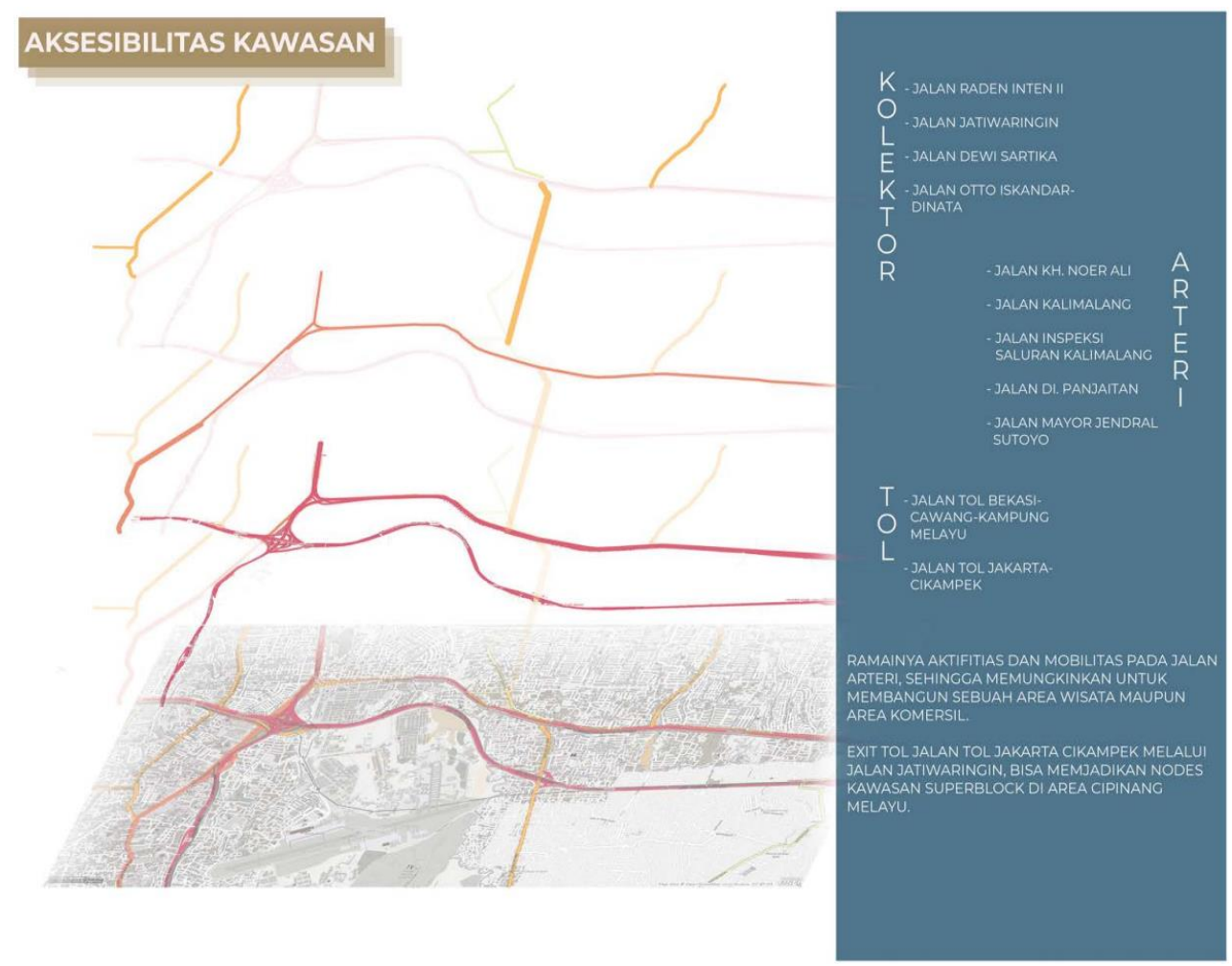

Gambar 7. Aksesibilitas Kawasan

Sumber: Dokumen pribadi

\section{USULAN PROGRAM FASILITAS PENGOLAHAN SAMPAH PLASTIK}

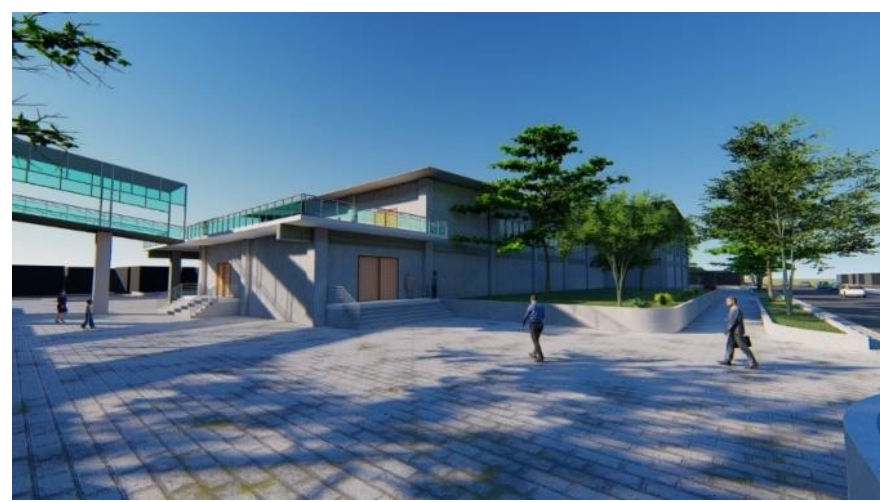

Gambar 8. Presfektif bangunan Pengolahan sampah plastik Sumber : Dokumen pribadi

Pusat Pengolahan Sampah Plastik disini adalah Upaya guna mengatasi masalah sampah plastik Jakarta. Salah satu kegiatan strategis daerah yang dilakukan yaitu pembangunan fasilitas pengolahan sampah dalam kota atau Intermediate Treatment Facility (ITF) untuk mengurangi sampah plastik dari sumbernya. Selain itu kegiatan strategis lainnya yaitu dengan melibatkan masyarakat setempat beserta perangkat daerahnya dengan menggiatkan kegiatan Bank Sampah masyarakat. 


\section{USULAN PROGRAM GALERI EDUKASI}

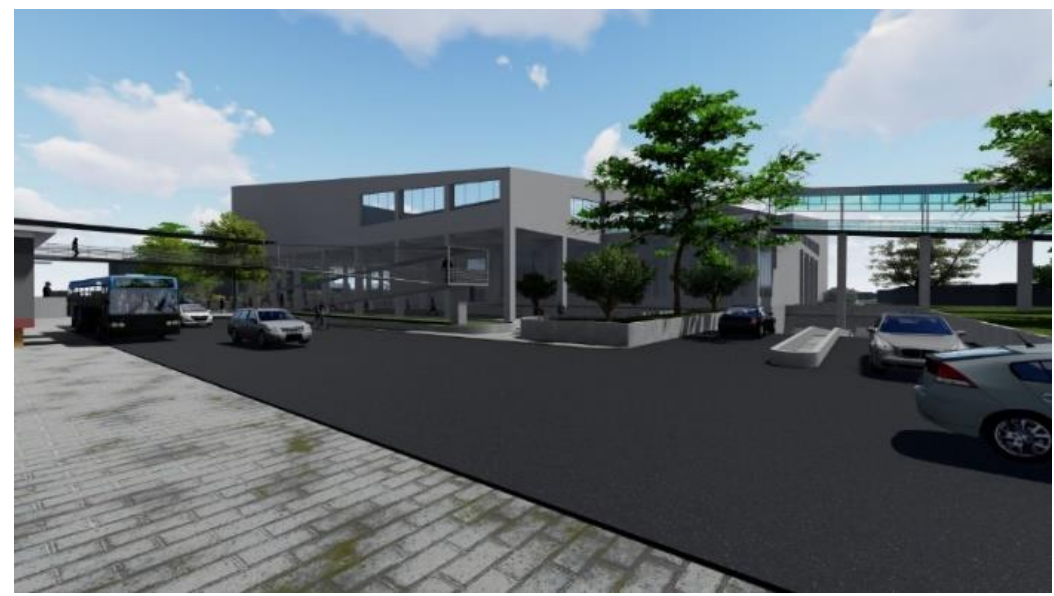

Gambar 9. Presfektif bangunan Galeri Edukasi

Sumber: Dokumentasi pibadi

Untuk progam edukasi disini diharapkan dapat meningkatkan kesadaran masyarakat akan pentingnya kepedulian terhadap sampah plastik, agar masyarakat sekitar Kampung Melayu bisa memperbaiki kebiasaan-kebiasaan membuang sampah sembarangan dan dapat mengolahnya menjadi sesuatu yang lebih berguna demi menjaga lingkungan sekitar.

Progam ini juga diharapkan dapat menjadi area rekreasi bagi masyarakat dan Kawasan sebagai tempat interaksi dan edukasi, sehingga dapat terus meningkatkan kesadaran masyarakat tentang bahaya sampah plastik kedepannya dan Dapat mengelola sampah Plastik sendiri dapat mengurangi kenaikan sampah plastik tiap tahunnya, lalu dapat Menjawab tema soal STUPA VIII yaitu Beyond Ecology. 


\section{Tabel Progam Ruang:}
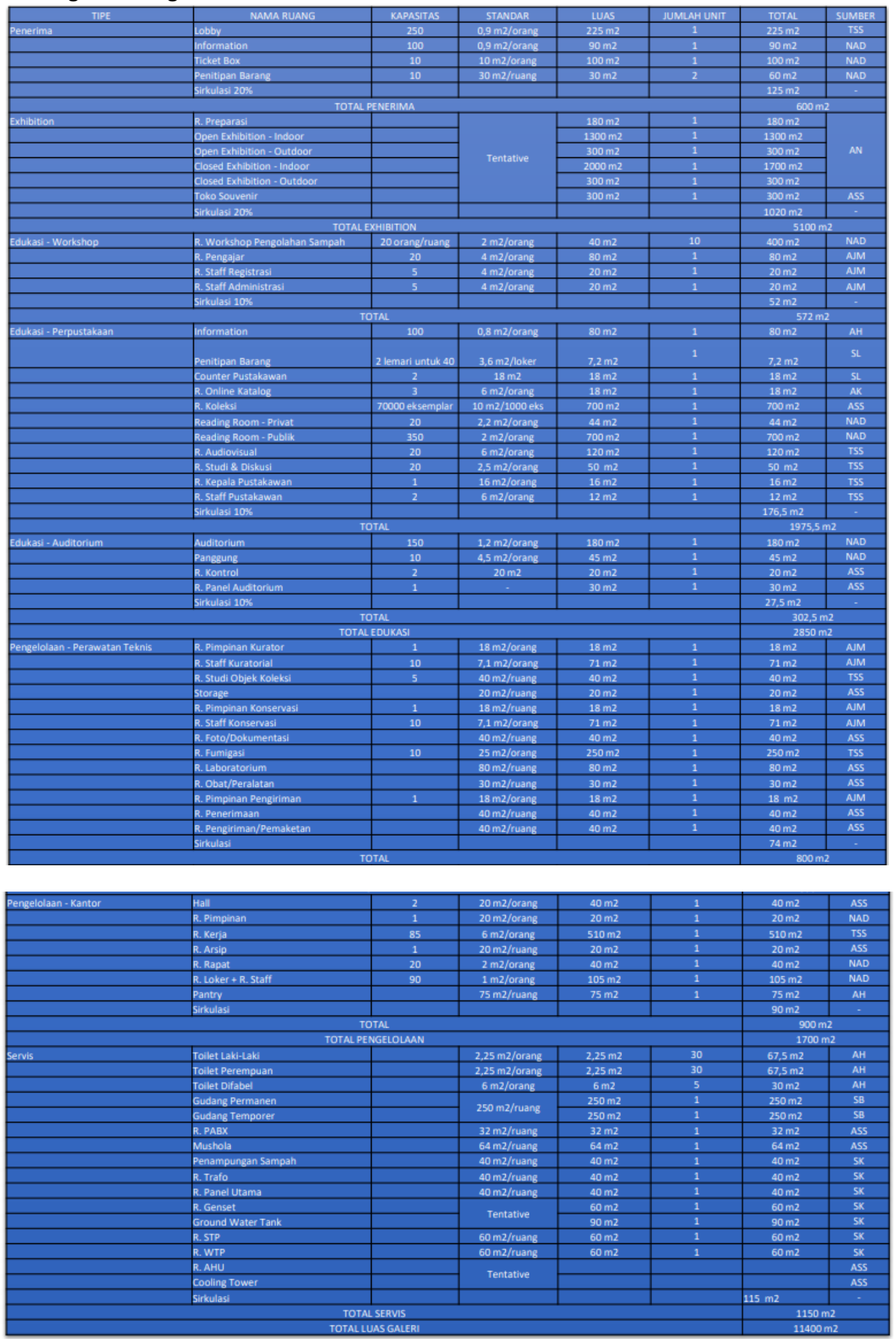

Gambar 10. Program Ruang

Sumber: Dokumentasi pibadi

EN : Ernst Neufert, Data Arsitek

TB : Joseph de Chiara, Time Standards for Building Types

SB : Studi Banding

As : Asumsi 


\section{PROSES GUBAHAN MASSA}

\section{1) BLOOK MASS}

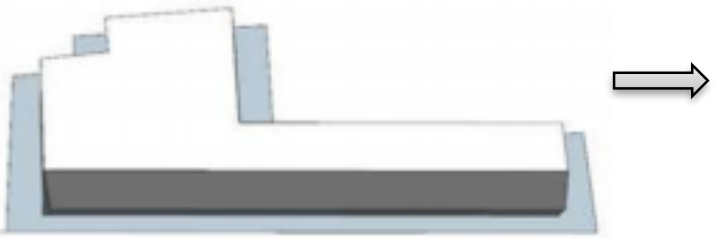

Blok massa mengikuti bentukan tapak dan lingkungan sekitar.

\section{2) SPLIT MASS}

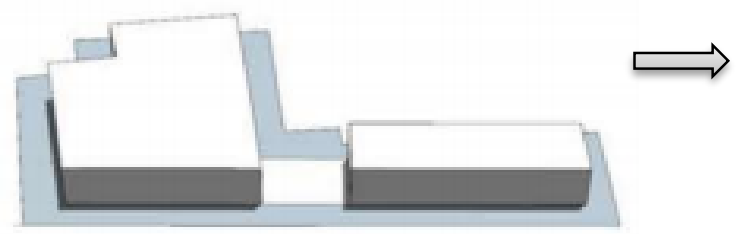

Blok massa kemudian dipisah dengan ruang terbuka antara bangunan edukasi galeri dan pengolahan sampah plastik.

\section{3) CROSS PEDESTRIAN}

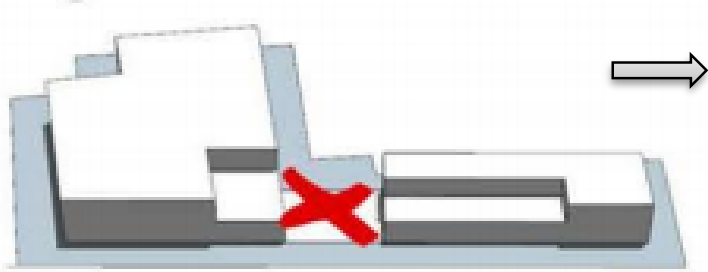

Mulai menyederhanakan massa untuk memikirkan koneksi antar massa, letak area balkon, dan jalur pejalan kaki.

\section{4) UTILIZE THE MASS}

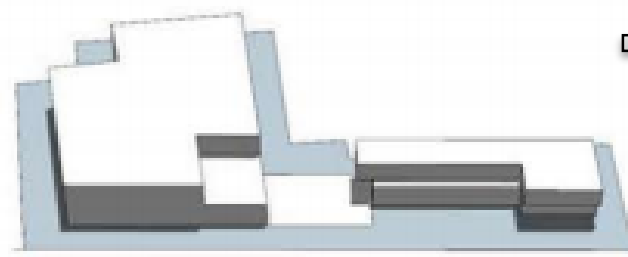

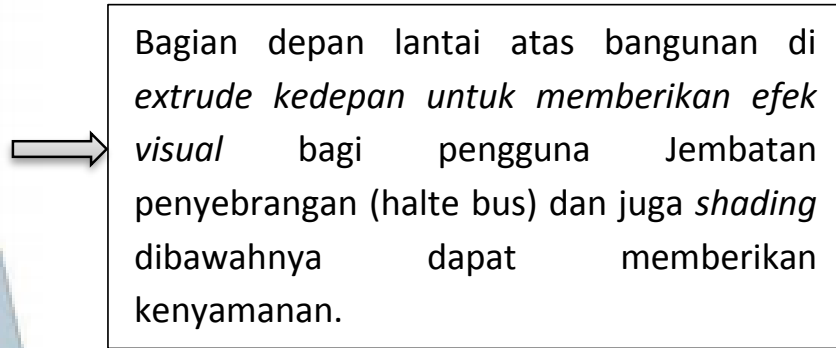

5) FINAL MASS

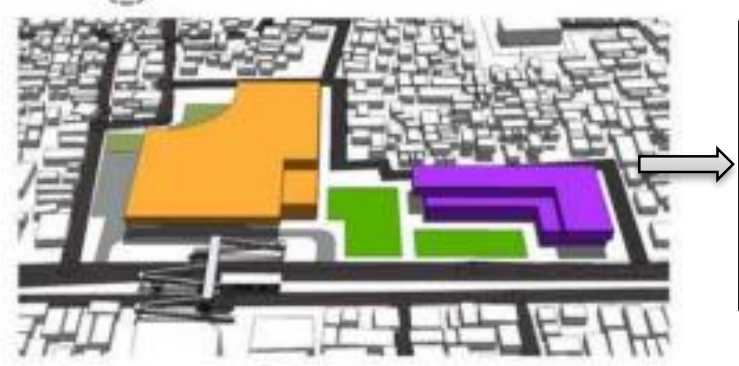

Bangunan terlihat beradaptasi dengan lingkungan sekitar dan bangunan juga terlihat memaksimalkan manfaat Transitoriented development (TOD) yang berada di depanya.

Gambar 11. Proses Gubahan Massa Sumber: Dokumentasi pribadi 


\section{KESIMPULAN DAN SARAN}

Perancangan Fasilitas Pengolahan Sampah Plastik dan Galeri Edukasi di Kampung Melayu ini diharapkan dapat menjadi refrensi dan informasi bagi berbagai pihak, baik masyarakat maupun pemerintahan untuk dapat lebih memperhatikan keadaan lingkungan di sekitar kita, salah satunya dengan penggunaan plastik secara lebih efektif dan terkontrol. Perancangan ini memberikan perhatian kepada bahayanya dari penggunaan material plastik yang tidak terkontrol dan tidak efektif.

Fasilitas Pengolahan Sampah Plastik dan Galeri Edukasi di Kampung Melayu ini juga bertujuan untuk menyadarkan seluruh masyarakat khususnya di Kampung Melayu (Jakarta Timur) untuk lebih menghargai lingkungan salah satunya dengan penggunaan material yang selama ini selalu masyarakat gunakan, yaitu material plastik, karena dampak yang ditimbulkan dari penggunaan material ini sangat besar bagi kehidupan di bumi.

\section{REFERENSI}

Adnan, M. Gempur. (2008). Statistik Persampahan Domestik Indonesia. Jakarta: Kementrian Negara Lingkungan Hidup Republik Indonesia (KNLH).

Altoon, R. A., \& James C.A. (2011). Urban Transformation Transit Oriented Development and Sustainable City. Australia : The Images Publishing.

Aryanti, N. (2013). Biopolimer sebagai Plastik Ramah Lingkungan. Universitas Diponegoro, Semarang : Buletin Teknologi Terapan Populer 1.

Isa, M. H. (2014). Arahan Pengembangan Kawasan Transit Berbasis Transit Oriented Development (TOD) Dalam Mendorong Penggunaan Kereta Komuter Koridor Surabaya Sidoarjo. Surabaya: Program Studi Perencanaan Wilayah dan Kota, ITS

Marten, G.G. (2001). Human Ecology : Basic Concepts for Sustainable Development. London, UK: Earthscan Publishing.

Odum, E. P. (1983). Basic Ecology : Saunders College Publishing. Tokyo, Japan: Hold - Saunders. Rambo, A. T. (1981). Human Ecology : Research on Tropical Agroecosystem in S. E. Asia. Singapore Journal of Tropical Geography 3: $86-99$.

Republik Indonesia Nomor 81, (2012), Undang-undang Pengelolaan Sampah Rumah Tangga dan Sampah Sejenis Rumah Tangga, Jakarta: Sekretariat Negara.

Steele, J. (1997). Sustainable Architecture: Principles, Paradigms, and Case Studies. Los Angeles: McGraw-Hill. 